\title{
Cyclophosphamide induces an early wave of acrolein-independent apoptosis in the urothelium
}

\author{
Francis M. Hughes ${ }^{1}$, Alexa G. Corn ${ }^{1}$, Andrew R. Nimmich ${ }^{1}$, Jeffery D. Pratt-Thomas ${ }^{1}$, \\ J. Todd Purves ${ }^{1,2,3}$ \\ ${ }^{1}$ Department of Urology, Medical University of South Carolina, Charleston, USA \\ ${ }^{2}$ Department of Pediatrics, Medical University of South Carolina, Charleston, USA \\ ${ }^{3}$ Department of Regenerative Medicine and Cell Biology, Medical University of South Carolina, Charleston, USA \\ Email: ${ }^{*}$ mhughes@musc.edu
}

Received 1 June 2013; revised 1 July 2013; accepted 16 July 2013

Copyright (C) 2013 Francis M. Hughes et al. This is an open access article distributed under the Creative Commons Attribution License, which permits unrestricted use, distribution, and reproduction in any medium, provided the original work is properly cited.

\begin{abstract}
Hemorrhagic cystitis (HC) affects a significant number of patients undergoing cyclophosphamide (CP) chemotherapy despite treatment with 2-mercaptoethane sulfonate (Mesna) to inactivate the metabolite acrolein. While the mechanism is unknown, there is clearly acrolein-independent damage to the urothelium. In this study we have explored the induction of apoptosis in the urothelium as a marker of damage and the mechanism underlying the acrolein-independent apoptosis. Two waves of apoptosis (measured as caspase-3/7 activity and Poly (ADP-ribosyl) polymerase (PARP) cleavage) were detected following CP administration, one peaking at $2 \mathrm{~h}$ and a second at 48 h. The first wave was not blocked by Mesna, indicating it was independent of acrolein. Caspase-1 was also active at $2 \mathrm{~h}$ and activation of caspase-3/7 was blocked by a caspase-1 inhibitor, but not an $\mathrm{IL}-1$ receptor antagonist, suggesting the direct activation of caspase-3/7 by caspase-1 without the need for IL-1 as an intermediate. Our results indicate that $\mathrm{CP}$ initiates an early, acrolein-independent wave of apoptosis that results from direct cleavage of caspase- $3 / 7$ by caspase-1.
\end{abstract}

Keywords: Cystitis; Cyclophosphamide; Apoptosis; Bladder; Urothelium

\section{INTRODUCTION}

Cyclophosphamide (CP) is a widely used chemotherapeutic agent that causes acute hemorrhagic cystitis (HC) [1]. A metabolite of $\mathrm{CP}$, acrolein, is largely responsible, leading oncologists to concomitantly administer 2-mer-

"Corresponding author. captoethane sulfonate (Mesna), an orally-available drug that masks acrolein's toxic effect. The use of Mesna has dramatically reduced, but not eliminated, $\mathrm{HC}$ [1-7] following $\mathrm{CP}$ chemotherapy. The mechanism for $\mathrm{HC}$ in the presence of Mesna has not been defined but clearly involves damage to the urothelium. A typical cellular response to damage is to initiate apoptosis in order to clear the damaged cell from the population. In this study, we have examined CP-induced damage to the urothelium in vivo using two independent markers of apoptosis: the activation of caspase(s)-3/7 and the cleavage of Poly (ADP-ribose) polymerase (PARP). Caspase-3/7 is considered an effector caspase and is activated in most models of apoptosis where it is directly involved in dismantling the cell by cleavage of structural and functional proteins. PARP is a DNA repair enzyme that is cleaved and inactivated ostensibly to conserve energy by not repairing DNA intentionally destroyed during the death process.

Recent studies have shown that damage to a cell or tissues is recognized by pattern recognition receptors which result in the activation of the inflammatory caspase, caspase-1 $[8,9]$. We have further examined the involvement of caspase-1 in the response to $\mathrm{CP}$ and the mechanism of its involvement.

\section{MATERIALS AND METHODS}

\subsection{Animals}

Adult female randomly cycling Sprague Dawley rats (175 - 199 g; Harlan, Prattville AL, USA) were used in all studies. All experimental protocols were approved by the Institutional Animal Care and Use Committee at our institution.

\subsection{Pharmacological Treatments}

Animals were injected (i.p.) with $80 \mathrm{mg} / \mathrm{kg} \mathrm{CP}$ or saline. 
We have previously shown that this dose induces changes in physiological bladder function indicative of $\mathrm{HC}$ within $24 \mathrm{~h}$ [10]. Following established protocols $[11,12]$ the Mesna animals received Mesna at $-0.5,4$ and $8 \mathrm{~h}$ relative to CP injection (Figure 1(a)). For caspase-1 inhibitor experiments Ac-Tyr-Val-Ala-Asp-2,6-dimethylbenzoyloxymethyl ketone (YVAD-AOM; EMD Chemicals, Rockland, MA, USA) was dissolved in DMSO (5 $\mathrm{mg} / \mathrm{ml}$ ), diluted in saline (to $200 \mu \mathrm{M}$ ), and $200 \mu \mathrm{l}$ (or 200 $\mu \mathrm{l}$ of $2.5 \%$ DMSO) was instilled transurethrally in anesthetized rats (ketamine/xylazine; $90 \mathrm{mg} / \mathrm{kg}$ and $10 \mathrm{mg} / \mathrm{kg}$ i.p., respectively). Catheters were capped and left indwelling. $1 \mathrm{~h}$ later rats were injected i.p. with $80 \mathrm{mg} / \mathrm{kg}$ $\mathrm{CP}$. One half hour later additional ketamine/xylazine (45 $\mathrm{mg} / \mathrm{kg}, 5 \mathrm{mg} / \mathrm{kg}$, respectively) was administered (i.p.). Two hours after $\mathrm{CP}$ injection rats were sacrificed. For anakinra experiments, rats were injected i.p. with 100 $\mathrm{mg} / \mathrm{kg}$ anakinra (Amgen, Thousand Oaks, CA, USA) in saline (or saline alone) $1 \mathrm{~h}$ prior to injection of $\mathrm{CP}$.

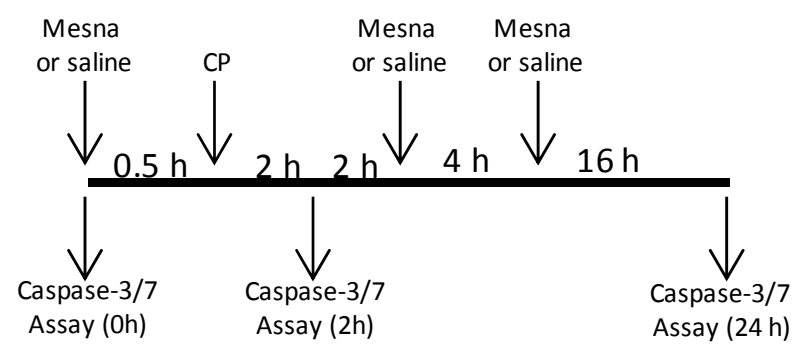

(a)

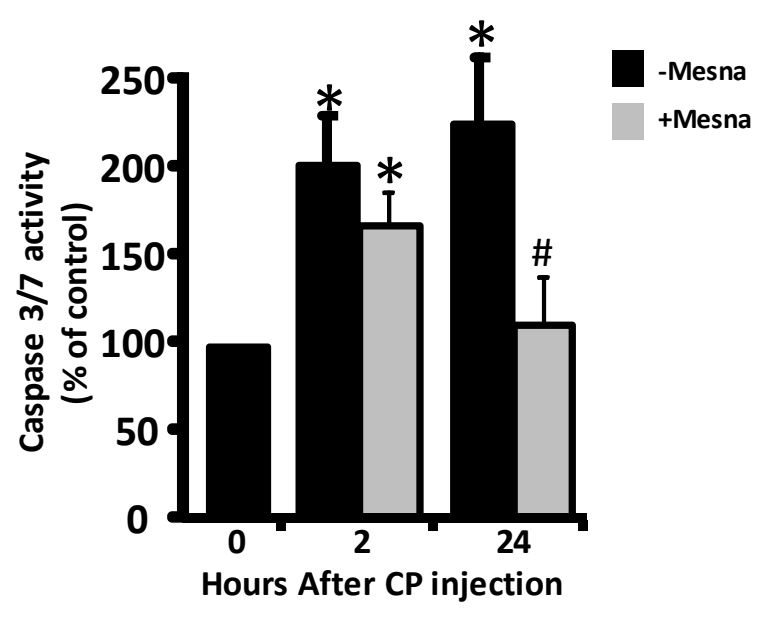

(b)

Figure 1. Ability of Mesna to block caspase-3/7 activity in urothelium 2 and $24 \mathrm{~h}$ after CP treatment. (a) Experimental protocol for treatment of rats with Mesna, CP and vehicle. (b) Caspase-3/7 activity in the samples indicated in a. Data points are the mean \pm SEM. Indicate values significantly different from the mean value at $0 \mathrm{~h} .(\mathrm{p}<0.05) . \mathrm{n}=4$ for $0 \mathrm{~h}$ and both 2 $\mathrm{h}$ time points. $\mathrm{n}=6$ for $24 \mathrm{~h}-$ Mesna and 3 for $24 \mathrm{~h}+$ Mesna. "Indicates the $24 \mathrm{~h}+$ Mesna group is significantly different from the $24 \mathrm{~h}-$ Mesna group $(\mathrm{p}<0.05)$. All other comparisons were not significant.

\subsection{Caspase Assays}

Urothelium were obtained by scraping, similar to what has been reported elsewhere [13,14]. Briefly, the isolated bladder was cut open from sphincter to dome. The dome ends were pinned and the sphincter held by forceps with a bent tip. The urothelium was gently scraped from the detrusor using a size 11 scalpel blade, twisting the blade to lift the cells. The cells were placed in ice-cold PBS, pelleted $(800 \times \mathrm{g}, 10 \mathrm{~min})$, resuspended in $25 \mu \mathrm{l}$ of 10 $\mathrm{mM} \mathrm{MgCl} 2,0.25 \%$ Igepal CA-630, mixed with an equal volume of $40 \mathrm{mM}$ Hepes (pH 7.4), $20 \mathrm{mM} \mathrm{NaCl}, 2 \mathrm{mM}$ EDTA, $20 \%$ Glycerol and stored at $-20{ }^{\circ} \mathrm{C}$ until analyzed ( $<1$ week).

Caspase-3/7 activity was measured using the Caspase Glo system from Promega Inc. (Madison, WI, USA) and the manufacturer's recommendations. Caspase-1 was analyzed similar to our previous studies [15]. Extracts $(20 \mu \mathrm{l})$ were combined with $50 \mu \mathrm{l}$ assay buffer $(25 \mathrm{mM}$ HEPES, 5\% sucrose, $0.05 \%$ CHAPS (pH 7.5)), $10 \mu 1100$ $\mathrm{mM}$ dithiothreitol and $20 \mu \mathrm{l} 1 \mathrm{mM}$ substrate (N-AcetylTyr-Val-Ala-Asp-7-amino-4-trifluoromethylcoumarin (Ac-YVAD-AFC); Enzo Life Sciences, Inc., Farmingdale, NY, USA) in blacked-walled 96 well plates. Fluorescence (Excitation $400 \mathrm{~nm}$, Emission $505 \mathrm{~nm}$ ) was measured every $30 \mathrm{sec}$ for $15 \mathrm{~min}$ and the slope determined. A standard curve of AFC was used to calculate specific activity.

\subsection{Analysis of Cleaved PARP}

Cells were resuspended in $1 \%$ paraformaldehyde and incubated in turn with $200 \mu \mathrm{l}$ of BD Bioscience's (San Jose, CA) FACS Permeabilization Solution-2 (10 min), 1 $\mathrm{ml}$ of $0.5 \%$ BSA in PBS (30 min), $100 \mu 1$ of anti-PARP (cleaved p85) rabbit monoclonal antibody (Epitomics, Burlingame, CA, USA; 1:50 dilution; $30 \mathrm{~min}$ ) and $200 \mu \mathrm{l}$ Alexa Fluor 488 conjugated goat anti-rabbit $\operatorname{IgG}(\mathrm{H}+\mathrm{L})$; Invitrogen (Life Technologies, Carlsbad, CA, USA; 1:500 dilution, $30 \mathrm{~min}$ ), with washing in between before being analyzed by flow cytometry.

\subsection{Statistics}

To test for differences over time (Figure 2), we modeled the $\log$ of percent difference from baseline (time $=0$ ) using linear regression with fixed effects for hours from baseline, treated as categorical variables. Regression model assumptions were evaluated using residual plots and QQ-plots. p-values represent tests that percent changes from baseline were different from 0 , and $p$ values $<0.05$ were considered significant. Other comparisons were conducted using non-parametric Wilcoxon rank sum tests or Student's t-test, as appropriate, and were also considered significant if $\mathrm{p}<0.05$. 


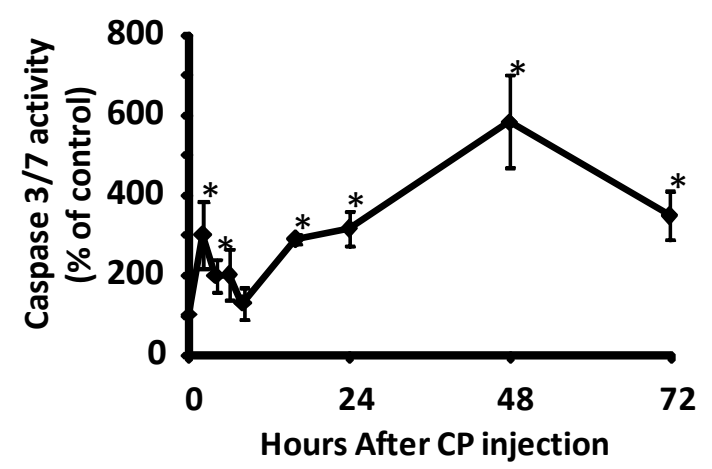

(a)

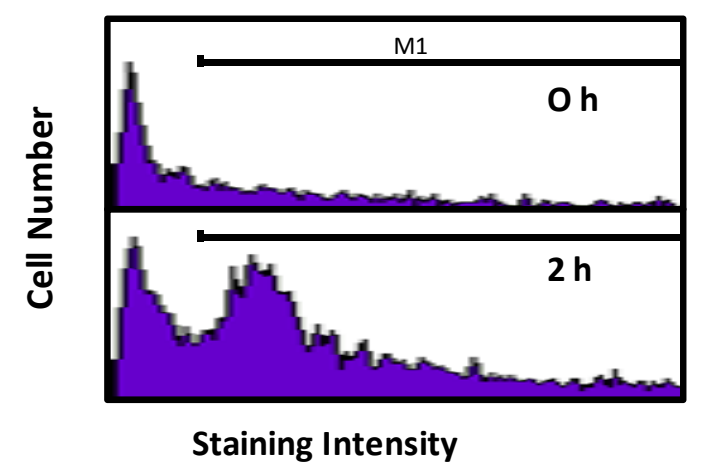

(b)

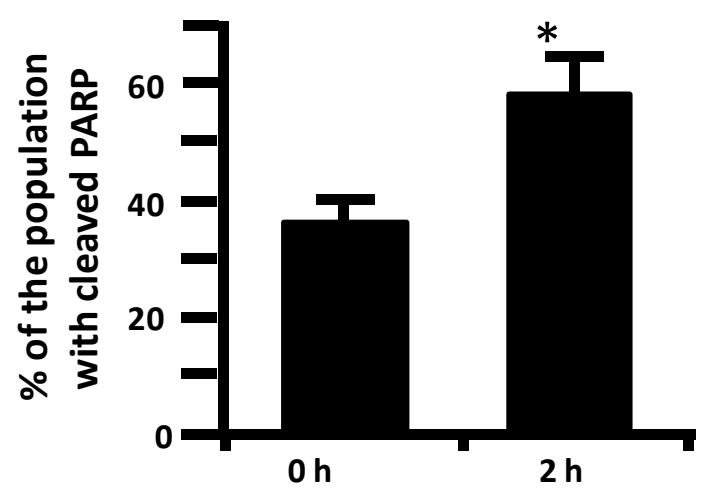

(c)

Figure 2. (a) Activity of caspase-3/7 in rat urothelium over time following injection of $80 \mathrm{mg} / \mathrm{kg} \mathrm{CP}$. Data points are the mean \pm SEM. Asterisks indicate values significantly different from $0 \mathrm{~h}(\mathrm{p}<0.0006$ at $2 \mathrm{~h},<$ 0.02 at $4 \mathrm{~h},<0.0015$ at $16 \mathrm{~h},<0.014$ at $24 \mathrm{~h},<0.0001$ at $48 \mathrm{~h}$ and $<0.007$ at $72 \mathrm{~h}$ ). $\mathrm{n}=3-6$ replicates. (b) Flowcytometry histograms showing the cell population staining positive (under the M1 gate) for cleaved PARP in rat urothelium 0 and $2 \mathrm{~h}$ following $80 \mathrm{mg} / \mathrm{kg}$ CP. (c) Quantitative analysis of b. Data points are the mean \pm SEM. Asterisks indicate significantly different from $0 \mathrm{~h}$ control. $\mathrm{n}=5 ; \mathrm{p}<0.05$.

\section{RESULTS}

\subsection{There Are Two Waves of Apoptosis Following CP Administration}

Caspase-3/7 activity in urothelium was followed for $72 \mathrm{~h}$ after the injection of $80 \mathrm{mg} / \mathrm{kg} \mathrm{CP}$. As shown in Figure 2(a), we detected a biphasic induction of apoptosis with an initial peak at $2 \mathrm{~h}$, followed by a return to baseline at $8 \mathrm{~h}$. At $16 \mathrm{~h}$, levels had increased again and continued to go up until at least the $48 \mathrm{~h}$ time point. While we have previously shown that this dosing paradigm induces changes in physiological bladder function indicative of $\mathrm{HC}$ at $24 \mathrm{~h} \mathrm{[10],} \mathrm{the} \mathrm{peak} \mathrm{at} 2 \mathrm{~h}$ is novel and is not associated with gross morphological change (data not shown). To confirm the $2 \mathrm{~h}$ result, we have examined expression of an independent apoptotic marker, cleaved PARP [16]. As shown in Figures 2(b) and (c), there was a $21.2 \%$ increase in the percentage of the urothelium cells with cleaved PARP at $2 \mathrm{~h}$ ( $\%$ of cells under the M1 gate).

\subsection{The First Wave of Caspase-3/7 Activity Is Independent of Acrolein}

To access the contribution of acrolein to the two waves of apoptosis, rats were pretreated with Mesna $0.5 \mathrm{~h}$ prior to CP administration. Due to the short half-life of Mesna [17], rats assessed at $24 \mathrm{~h}$ also received additional doses of Mesna at 4 and $8 \mathrm{~h}[11,12]$ (Figure 1(a)). As shown in Figure 1(b), Mesna significantly $(p<0.05)$ reduced the caspase-3/7 activity in urothelium at $24 \mathrm{~h}$ but only slightly and non-significantly reduced the activity at $2 \mathrm{~h}$, indicating that the early peak of apoptosis is mostly acrolein-independent while the latter wave is largely dependent on this metabolite.

\subsection{A Caspase-1 Inhibitor, But Not an IL-1 Receptor Antagonist, Blocks Activation of Caspase-3/7 at 2 h}

Damage to a cell or tissue often results in the activation of caspase-1. As shown in Figure 3(a), we detect significant activation of caspase- 1 two hours after CP administration, further indicating urothelium damage at this time point. Working upstream, caspase-1 can cleave caspase-3/7 directly [18,19] or stimulate apoptosis through production of IL-1 $\beta[20,21]$. Direct luminal instillation of the caspase-1 inhibitor YVAD-AOM blocked the increase in caspase-3/7 activity stimulated by CP after $2 \mathrm{~h}$ (Figure 3(b)). Caspase-3/7 activity was significantly (p $<0.05)$ stimulated by $\mathrm{CP}$ in rats that were not pretreated with anakinra (an IL-1 receptor antagonist) and in ones that were pretreated (Figure 3(c)). In addition, there was no significant $(\mathrm{p}=0.28)$ difference noted between the anakinra pretreated and saline rats which did not receive $\mathrm{CP}$, and there was no significant $(\mathrm{p}=0.10)$ difference noted between the anakinra pretreated and saline rats which did receive CP. In other words, pretreatment of rats with the IL-1 $\beta$ receptor antagonist anakinra had no effect (Figure 3(c)). 


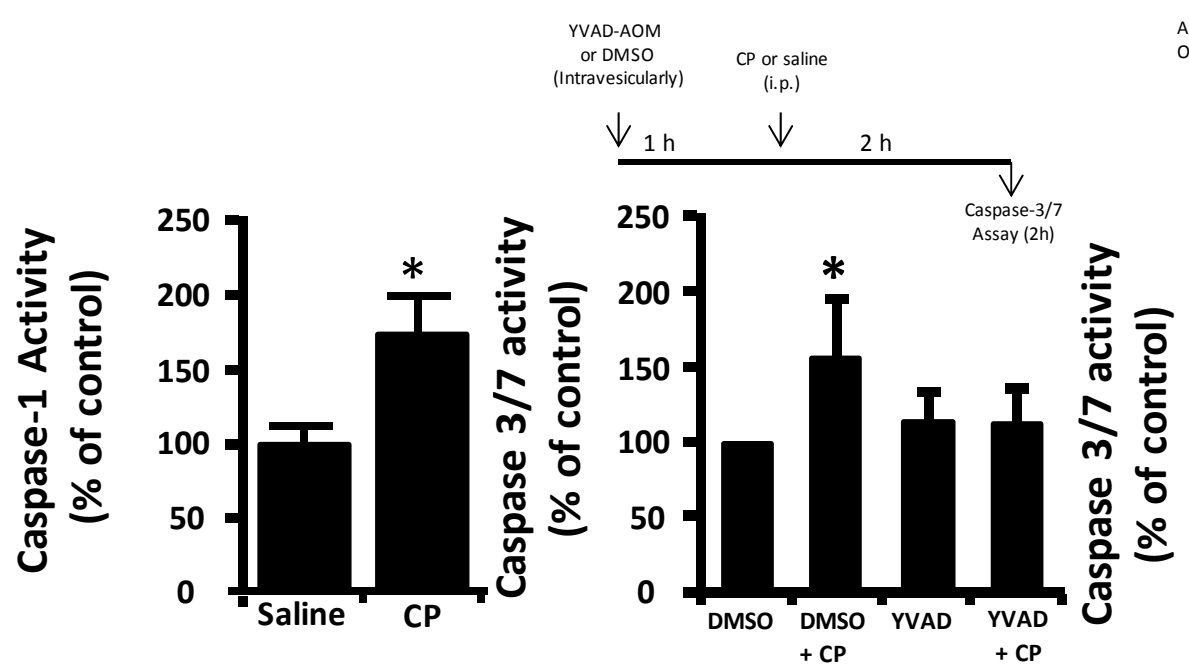

(a)

(b)

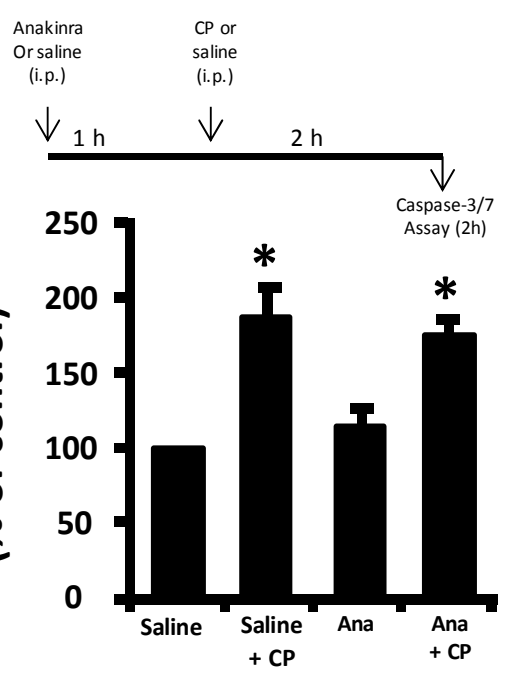

(c)

Figure 3. (a) Caspase-1 activity in rat urothelium $2 \mathrm{~h}$ after injection of $80 \mathrm{mg} / \mathrm{kg} \mathrm{CP}$ or saline control. Data points are the mean \pm SEM. Asterisks indicate values significantly different from the mean value at $0 \mathrm{~h}, \mathrm{n}=6, \mathrm{p}<0.05$. (b) (upper) diagram of the protocol for treatment with YVAD-AOM, CP and DMSO. (b) (lower) caspase-3/7 activity in the various treatment groups. Data points are mean \pm SEM. Asterisks indicate values significantly different from DMSO control; $n=6, p<0.05$. No other differences between groups were significant. (c) (upper) diagram of the protocol for treatment with Anakinra (Ana), CP and saline. (c) (lower) caspase-3/7 activity in the various treatment groups. Data points are mean \pm SEM. Asterisks indicate values significantly different from saline control; $n=5-6, p<0.05$. No other differences between groups were significant.

\section{DISCUSSION}

CP-induced damage to the urothelium is clearly involved in the induction of HC. While the metabolite acrolein is largely responsible for this, the persistence of significant levels of this malady in the presence of Mesna suggests additional damage must occur. Since damage to cells often activates apoptosis, we examined the increase of this death process as an indicator of damage in response to CP. In these studies we have used a smaller dose of CP than is often used with rodents [22,23] but one we have previously documented to induce changes in physiological bladder function indicative of $\mathrm{HC}$ by $24 \mathrm{~h}$ [10]. Moreover, this dose was chosen from our institution's protocols for treating patients with acute lymphocytic leukemia.

Using caspase-3/7 activity as a measurement of apoptosis, we detected a biphasic response with waves peaking at 2 and $48 \mathrm{~h}$. The peak at 2 hours is novel and the inclusion of Mesna had an insignificant effect at this time. The rise in cell death at $24 \mathrm{~h}$ is consistent with Jezernik et al. [24], although they did not find significant apoptosis at 1 or $6 \mathrm{~h}$ following CP. Given the transient nature of the early wave at $2 \mathrm{~h}$ it is possible that Jezernik et al. bracketed the peak and thus did not detect significant levels of cell death. Importantly, we have confirmed the $2 \mathrm{~h}$ result using an independent apoptotic marker; cleaved PARP, which also provided an estimate of the population effected $(21.2 \% \pm 4.9 \%)$. Consequently, our results indicate acrolein-independent damage to the uro- thelium early following $\mathrm{CP}$ administration and we sought to explore this change further.

Recent studies have begun to delineate how damage is sensed in a tissue and the results show a central role for pattern recognition receptors and the activation of caspase-1 [8,9]. Indeed, we detected caspase- 1 activated at 2 $\mathrm{h}$ following CP treatment, providing further evidence of tissue damage at this time. This result also suggested two possible links between activation of this inflammatory caspase and the downstream effector caspase; caspase$3 / 7$. Caspase- 1 can directly cleave caspase- $3 / 7[18,19]$ or activate IL-1 $\beta$, which itself may induce apoptosis and result in the activation of caspase-3/7 [20,21]. To differentiate between these possibilities we used a caspase-3/7 inhibitor (YVAD-AOM) and a IL-1 receptor antagonist (anakinra). While the caspase-1 inhibitor blocks the activation of caspase-3/7, anakinra had no effect which argues strongly for the direct activation of caspase- $3 / 7$ without IL- $1 \beta$ as an intermediate. While IL-1 $\beta$ is most certainly produced in our model, it is not implicated in the initial wave of apoptosis at $2 \mathrm{~h}$.

Our results demonstrate that a single dose of $\mathrm{CP}$ at clinically relevant levels [10] can initiate an early wave of damage in the urothelium resulting in the activation of caspase- 1 and apoptosis. How these events could precipitate later $\mathrm{HC}$ is unknown. Interestingly, recent work with herpes virus demonstrates that apoptosis can reactivate this virus $[25,26]$. Considering that reactivation of $\mathrm{BK}$ virus (latently present in $90 \%$ of adults) has been strongly implicated in the pathology underlying $\mathrm{HC}$ in Mesna- 
treated patients $[3,27,28]$, it is tempting to speculate that apoptotic-induced viral reactivation may be involved.

Our results indicate that CP initiates an early, acroleinindependent wave of apoptosis that results from direct cleavage of caspase-3/7 by caspase- 1 .

\section{ACKNOWLEDGEMENTS}

The authors would like to thank Dr. Elizabeth Garrett-Mayer and Dr. Paul J. Nietert for their expert assistance with statistical analysis of our data. The project described was supported by Award Number UL1RR029882 and UL1TR000062 from the National Center for Research Resources. The content is solely the responsibility of the authors and does not necessarily represent the official views of the National Center for Research Resources or the National Institutes of Health.

\section{REFERENCES}

[1] Hu, R.Q., Mehter, H., Nadasdy, T., Satoskar, A., Spetie, D.N., Rovin, B.H. and Hebert, L. (2008) Severe hemorrhagic cystitis associated with prolonged oral cyclophosphamide therapy: Case report and literature review. Rheumatology International, 28, 1161-1164. doi:10.1007/s00296-008-0581-0

[2] Haselberger, M.B. and Schwinghammer, T.L. (1995) Efficacy of mesna for prevention of hemorrhagic cystitis after high-dose cyclophosphamide therapy. The Annals of Pharmacotherapy, 29, 918-921.

[3] Cesaro, S., Hirsch, H.H., Faraci, M., Owoc-Lempach, J., Beltrame, A., Tendas, A., Baltadakis, I., Dalle, J.H., Koc, Y., Toporski, J., Styczynski, J., Yesilipek, M.A., Heinz, W., Caniglia, M., Rascon, J., Fauser, A.A., Michallet, M., Lopez-Corral, L., Neuburger, S., Tridello, G. and Einsele, H. (2009) Cidofovir for BK virus-associated hemorrhagic cystitis: A retrospective study. Clinical Infectious Diseases, 49, 233-240. doi:10.1086/599829

[4] Dropulic, L.K. and Jones, R.J. (2008) Polyomavirus BK infection in blood and marrow transplant recipients. Bone Marrow Transplant, 41, 11-18.

doi:10.1038/sj.bmt.1705886

[5] Harkensee, C., Vasdev, N., Gennery, A.R., Willetts, I.E. and Taylor, C. (2008) Prevention and management of BK-virus associated haemorrhagic cystitis in children following haematopoietic stem cell transplantation-A systematic review and evidence-based guidance for clinical management. British Journal of Haematology, 142, 717-731. doi:10.1111/j.1365-2141.2008.07254.x

[6] Megged, O., Stein, J., Ben-Meir, D., Shulman, L.M., Yaniv, I., Shalit, I. and Levy, I. (2011) BK-virus-associated hemorrhagic cystitis in children after hematopoietic stem cell transplantation. Journal of Pediatric Hematology/Oncology, 33, 190-193. doi:10.1097/MPH.0b013e3181fce388

[7] Silva Lde, P., Patah, P.A., Saliba, R.M., Szewczyk, N.A., Gilman, L., Neumann, J., Han, X.Y., Tarrand, J., Ribeiro, R., Gulbis, A., Shpall, E.J., Jones, R., Popat, U., Walker, J.A., Petropoulos, D., Chiattone, A., Stewart, J., El-Zimaity, M. anderlini, P., Giralt, S., Champlin, R.E. and de
Lima, M. (2010) Hemorrhagic cystitis after allogeneic hematopoietic stem cell transplants is the complex result of BK virus infection, preparative regimen intensity and donor type. Haematologica, 95, 1183-1190. doi:10.3324/haematol.2009.016758

[8] Henao-Mejia, J., Elinav, E., Strowig, T. and Flavell, R.A. (2012) Inflammasomes: Far beyond inflammation. Nature Immunology, 13, 321-324. doi:10.1038/ni.2257

[9] Gross, O., Thomas, C.J., Guarda, G. and Tschopp, J. (2011) The inflammasome: An integrated view. Immunological Reviews, 243, 136-151. doi:10.1111/j.1600-065X.2011.01046.X

[10] Hughes, F.M., Jr., McKeithan, P., Ellett, J., Armeson, K.E. and Purves, J.T. (2013) Simvastatin suppresses cyclophosphamide-induced changes in urodynamics and bladder inflammation. Urology, 81, e209-e209, e214. doi:10.1016/j.urology.2012.08.041

[11] Kanat, O., Kurt, E., Yalcinkaya, U., Evrensel, T. and Manavoglu, O. (2006) Comparison of uroprotective efficacy of mesna and amifostine in cyclophosphamide-induced hemorrhagic cystitis in rats. Indian Journal of Cancer, 43, 12-15. doi:10.4103/0019-509X.25769

[12] Kyung, Y.S., Park, H.Y. and Lee, G. (2011) Preservation of uroplakins by 2-mercaptoethanesulfonate in cyclophosphamide-induced rat cystitis. Archives of Toxicology, 85, 51-57. doi:10.1007/s00204-010-0523-y

[13] Haefliger, J.A., Tissieres, P., Tawadros, T., Formenton, A., Beny, J.L., Nicod, P., Frey, P. and Meda, P. (2002) Connexins 43 and 26 are differentially increased after rat bladder outlet obstruction. Experimental Cell Research, 274, 216-225. doi:10.1006/excr.2001.5465

[14] Masui, T., Mann, A.M., Macatee, T.L., Okamura, T., Garland, E.M., Smith, R.A. and Cohen, S.M. (1992) Absence of ras oncogene activation in rat urinary bladder carcinomas induced by N-methyl-N-nitrosourea or N-butyl-N-(4-hydroxybutyl)nitrosamine. Carcinogenesis, 13, 22812285. doi:10.1093/carcin/13.12.2281

[15] Hughes, F.M., Jr., Bortner, C.D., Purdy, G.D. and Cidlowski, J.A. (1997) Intracellular K+ suppresses the activation of apoptosis in lymphocytes. The Journal of Biological Chemistry, 272, 30567-30576.

doi: $10.1074 / \mathrm{jbc} .272 .48 .30567$

[16] Rosen, A. and Casciola-Rosen, L. (1997) Macromolecular substrates for the ICE-like proteases during apoptosis. Journal of Cellular Biochemistry, 64, 50-54. doi:10.1002/(SICI)1097-4644(199701)64:1<50::AID-JC B8>3.0.CO;2-Z

[17] Bagley, C.M.J., Bostick, F.W. and DeVita, V.T.J. (1973) Clinical pharmacology of cyclophosphamide. Cancer Research, 33, 226-233.

[18] Lamkanfi, M. and Kanneganti, T.D. (2010) Caspase-7: A protease involved in apoptosis and inflammation. The International Journal of Biochemistry \& Cell Biology, 42, 21-24. doi:10.1016/j.biocel.2009.09.013

[19] Van de Craen, M., Declercq, W., Van den brande, I., Fiers, W. and Vandenabeele, P. (1999) The proteolytic procaspase activation network: An in vitro analysis. Cell Death \& Differentiation, 6, 1117-1124. doi:10.1038/sj.cdd.4400589 
[20] Ferdaoussi, M., Abdelli, S., Yang, J.Y., Cornu, M., Niederhauser, G., Favre, D., Widmann, C., Regazzi, R., Thorens, B., Waeber, G. and Abderrahmani, A. (2008) Exendin-4 protects beta-cells from interleukin-1 beta-induced apoptosis by interfering with the c-Jun NH2-terminal kinase pathway. Diabetes, 57, 1205-1215. doi: $10.2337 / \mathrm{db} 07-1214$

[21] Li, L., El-Kholy, W., Rhodes, C.J. and Brubaker, P.L. (2005) Glucagon-like peptide-1 protects beta cells from cytokine-induced apoptosis and necrosis: Role of protein kinase B. Diabetologia, 48, 1339-1349. doi:10.1007/s00125-005-1787-2

[22] Arms, L., Girard, B.M. and Vizzard, M.A. (2010) Expression and function of CXCL12/CXCR4 in rat urinary bladder with cyclophosphamide-induced cystitis. Renal Physiology: American Journal of Physiology, 298, F589F600. doi:10.1152/ajprenal.00628.2009

[23] Corrow, K.A. and Vizzard, M.A. (2007) Phosphorylation of extracellular signal-regulated kinases in urinary bladder in rats with cyclophosphamide-induced cystitis. American Journal of Physiology-Regulatory, Integrative and Comparative Physiology, 293, R125-134. doi:10.1152/ajpregu.00857.2006

[24] Jezernik, K., Romih, R., Mannherz, H.G. and Koprivec, D. (2003) Immunohistochemical detection of apoptosis, proliferation and inducible nitric oxide synthase in rat urothelium damaged by cyclophosphamide treatment. Cell Biology International, 27, 863-869. doi:10.1016/S1065-6995(03)00175-6

[25] Du, T., Zhou, G. and Roizman, B. (2012) Induction of apoptosis accelerates reactivation of latent HSV-1 in ganglionic organ cultures and replication in cell cultures. Proceedings of the National Academy of Sciences USA, 109, 14616-14621. doi:10.1073/pnas. 1212661109

[26] Hunsperger, E.A. and Wilcox, C.L. (2003) Caspase-3dependent reactivation of latent herpes simplex virus type 1 in sensory neuronal cultures. Journal of NeuroVirology, 9, 390-398. doi:10.1080/13550280390201678

[27] Babel, N., Volk, H.D. and Reinke, P. (2011) BK polyomavirus infection and nephropathy: The virus-immune system interplay. Nature Reviews, 7, 399-406. doi:10.1038/nrneph.2011.59

[28] Miller, A.N., Glode, A., Hogan, K.R., Schaub, C., Kramer, C., Stuart, R.K. and Costa, L.J. (2011) Efficacy and safety of ciprofloxacin for prophylaxis of polyomavirus $\mathrm{BK}$ virus-associated hemorrhagic cystitis in allogeneic hematopoietic stem cell transplantation recipients. Biology of Blood and Marrow Transplantation, 17, 11761181. doi:10.1016/j.bbmt.2010.12.700 